\title{
Assessment during the Integration of Lesson Study in Microteaching among Pre-service Teachers
}

\author{
Zanaton H Iksan ${ }^{1}$, Siti NorAishah Mohd Nor ${ }^{1} \&$ Siti NorAini Mohd Nor ${ }^{2}$ \\ ${ }^{1}$ Faculty of Education, Universiti Kebangsaan Malaysia, Selangor, Malaysia \\ ${ }^{2}$ SMK Sultan Ibrahim, Kulai, Malaysia \\ Correspondence: Zanaton H Iksan, Faculty of Education, Universiti Kebangsaan Malaysia, 43600 UKM Bangi, \\ Selangor, Malaysia. Tel: 60-3-8921-6252. E-mail: naim@ukm.my
}

\author{
Received: August 16, 2013 Accepted: October 14, 2013 Online Published: November 28, 2013 \\ doi:10.5539/ass.v9n16p112 URL: http://dx.doi.org/10.5539/ass.v9n16p112
}

\begin{abstract}
Lesson Study is an approach used for critical analysis during the teaching and learning process. The effectiveness of this approach was proven when the Ministry of Education implemented it by stages in schools. This approach was also used to enhance the development process in the teaching profession. In conjunction with this, the science program students from the Faculty of Education were also given early exposure to Lesson Study. This approach was applied by integrating it in the teaching methods through simulated microteaching. Thus, the purpose of this study was to observe the assessment process in microteaching, which integrated with the approach of Lesson Study. This study was carried out in the Chemical Teaching Methods Course in the Faculty of Education, Universiti Kebangsaan Malaysia (UKM). It focused on how the pre-service teachers assessed the elements in microteaching. A total of 27 pre-service teachers were involved in the qualitative study. This study was carried out in one 14-weeks semester. This study involved the collection and qualitative analysis of data. Data sources were derived from observation, interviews, written reports by pre-service teachers, audio recordings (mp3), and video that was transcribed verbatim. Triangulation was done on each of the data sources. The findings showed that, through Lesson Study in microteaching, pre-service teachers were able to construct skills in doing assessment based on the lesson plan, teaching approach, and students' behaviour. Findings from this study had a positive impact on the pre-service teachers in making assessments. This is due to the fact that the microteaching of Lesson Study allowed the pre-service teachers to construct their skills in doing assessments during the lessons. The construction of these skills is important because of the school-based assessment that focuses on the assessment process is being implemented in the school curriculum in Malaysia. Hence, the construction of skills to assess the entire lesson process is very significant for the pre-service teachers.
\end{abstract}

Keywords: microteaching, Lesson Study, evaluation skills, teaching and learning, pre-service teacher

\section{Introduction}

School-based assessment was introduced in the curriculum in Malaysia in 2010 under the Kurikulum Standard Prasekolah Kebangsaan (KSPK) and Kurikulum Standard Sekolah Rendah (KSSR) (Curriculum Development Centre, 2011). This assessment is an indicator of the students' achievements during the teaching and learning process (Muniarti \& Radhi, 2010). Therefore, teachers must have the skills to do the assessment during the lesson.

This situation will have an indirect impact on teacher training. Through teacher training, the pre-service teachers construct their skills to plan, to teach, and to assess the lesson process via microteaching (Kilic, 2010). However, mistakes in the teaching elements kept being repeated, even though they had already received comments from their lecturers and peer evaluators. The peer evaluators who commented on their friends' mistakes (as the teacher who taught) also did the same mistakes. The reason is that they were inexperienced in teaching. Therefore, improvement should be made to ensure that microteaching has a positive impact on the pre-service teachers (Amobi, 2005). Besides, there are also several other problems that arise during its implementation. Among them, there are several pre-service teachers with problems in making assessments based on the lesson plan (Mergler \& Tangen, 2010), making unspecific assessments on simulated teaching (Eksi, 2012), always giving repeated criticism (Gunn, 2010), and not focusing on each step of simulated teaching, such as the set induction step, expansion, and closure (Kilic, 2010). Hence, the uncritical assessment of simulated teaching led to the failure of 
the pre-service teachers in making quality analyses of lessons (Burden \& Byrd, 2003).

Therefore, improvements in microteaching should be made to maximize the positive result and to minimize the problems. Another alternative that has been suggested is an investigation method during the teaching and learning process to help the pre-service teachers to construct their skills in assessing lessons (Burden \& Byrd, 2003), and one of the effective and proven investigation methods during lessons is Lesson Study (Teacher Education Centre, 2011).

Studies have proven the effectiveness of Lesson Study as a strategy that helps teachers to improve teaching practices, including the skills to assess the lesson (Chassels \& Melville, 2009). Thus, exposure to the implementation of Lesson Study is crucial to the pre-service teachers. The integration of Lesson Study and microteaching are able to help pre-service teachers in making effective investigations of lessons (Fernandez, 2010). In fact, this integration can help the teachers to construct skills in assessment and reflection towards the lesson (Chassels \& Melville, 2009). Thus, the purpose of this study is to explore the assessment process done by pre-service teachers in microteaching, integrating Lesson Study approaches.

\section{Assessment in Microteaching}

Assessment is an essential element in the teaching and learning process. Through assessment, pre-service teachers can gather information about the effectiveness of a lesson. In microteaching, the assessment is focused on the lesson in which the pre-service teachers assess all the elements involved in the teaching process done by their peers, and all the pre-service teachers are involved in making the assessment. In other words, the pre-service teachers will take turns teaching and assessing their peers. This practice provides an opportunity for all the pre-service teachers to learn every teaching element from each other.

Microteaching is simulated teacher training that is carried out by pre-service teachers. The aim of this training is to construct pre-service teachers' skills in teaching and learning activity (Mok Soon Sang, 2012). Besides, this simulation training gives direct exposure to the pre-service teachers because each is required to teach in class. The three crucial skills emphasized in microteaching are the preparation of lesson plans, teaching, and lesson assessment (Amobi, 2005). The assessment is done by students who are chosen from the pre-service teachers in the microteaching classroom. The implementation of microteaching is done by assigning a pre-service teacher to teach by himself/herself, while the rest act as students in a classroom that is nearly similar to a real situation (Eksi, 2012; Amobi, 2005). In addition, several of them are appointed to be cameramen. The pre-service teachers are required to teach approximately 30 to 40 minutes. The general steps in microteaching include all three crucial skills.

\section{Lesson Study}

In Japanese, Lesson Study is known as Jugyokenkyu, which means "research study." The term Lesson Study was introduced by Makoto Yoshida, an expert who has extensive experience in this field (Takahashi et al., 2006). The main objectives of its implementation are to train teachers to be more responsible towards students' learning and to enhance the effectiveness of their teaching practices (Saito \& Sato, 2012). Hence, the high awareness of teachers in Japan towards their responsibility in the implementation of Lesson Study has led to the production of high achieving students (Lewis et al., 2004). This success has prompted researchers to identify the practices of the Japanese educational system (Perry \& Lewis, 2009). The research then had led to the discovery of Lesson Study.

In Japan, the pre-service teachers are exposed to Lesson Study during their teacher preparation courses. The implementation of Lesson Study in the pre-service teachers' courses involves collaboration between experienced teachers, mentors, and professors in the educational field, as well as other teachers (Fernandez \& Yoshida, 2004). Indeed, Lesson Study is a development medium that helps novice and senior teachers (Fernandez, 2005), and Lesson Study also can be implemented by the collaboration between teachers from different schools who teach the same subject. Nevertheless, the most popular group for Lesson Study consists of teachers from the same school. In Lesson Study, teachers collaborate to prepare the lesson plan, to teach in the classroom, and to complete the assessment for the whole lesson process. In fact, after discussion about the assessment for the lesson, the lesson plan that has been prepared in the early stages will be revised and improved if necessary.

Lewis (2002a) introduced four main steps in the Lesson Study cycle. The first step is the formation of long-term goals that emphasize the development of students as a whole. The second step is to plan the teaching and learning session to achieve the goals (Lewis et al., 2006). Next, a teacher is appointed to teach the lesson while others observe and assess during the lesson (Lewis et al., 2004). The fourth and last step is a discussion about the assessment made during the lesson. 
The discussion session starts with self-reflection by the teacher who teaches the lesson, followed by the findings from the observation. Discussion on the assessment should focus on the data collected and the learning evidence with the purpose of improving the lesson that the teachers had planned together (Lewis et al., 2006). The experts can be engaged in this cycle. Lewis (2002a) stressed that cooperative collaboration needs to be applied during the whole cycle. If the outcome of the first lesson is not excellent, a new lesson plan will be prepared, and the weaknesses identified from the first lesson will be the guideline to make the improvements. Then, the second lesson and its assessments are carried out based on the new lesson plan (Lewis, 2002b).

There are similarities and differences between the implementation of the steps in microteaching and Lesson Study. The Lesson Study cycle stresses the collaboration aspect in all the implementation steps, while in microteaching pre-service teachers implement the teaching steps individually. In addition, in the assessment, the evaluators' main task in microteaching is to make observations of the teacher's teaching skills, such as questioning skills, the use of examples to make the lesson more interesting, reinforcement, opening and ending the lesson, and the learning process. On the other hand, in Lesson Study, the evaluators' main task is to assess the achievement of students' learning objectives through the implementation of the teaching development that was prepared beforehand (Matthews et al., 2009). In other words, as Matthews explained, evaluators observe the ability of the lesson plan to achieve the students' learning objectives that were prepared beforehand. In addition, in Lesson Study, the evaluators need to be in a position to observe students' behaviour without intervening in the lesson (Watanabe, 2002). This is contrasted with the assessment process in microteaching, in which the evaluators' position is not emphasized.

\section{Methodology}

This study was carried out based on the descriptive qualitative study's design by using the purposive sampling to obtain appropriate respondents (Creswell, 2012). Respondents consisted of 27 students from the Science Programme in the Chemistry Teaching Methods course in Faculty of Education, Universiti Kebangsaan Malaysia (UKM). The course has integrated Lesson Study in microteaching, known as Microteaching Lesson Study (MLS). In this article, the discussion starts with the implementation of MLS, followed by an explanation about data collection and analysis. The implementation of MLS was carried out in one semester (14 weeks). Every week, a group carried out a lesson within 40 to 45 minutes. After each lesson, there was a discussion about the lesson. Each session of teaching and learning was recorded with a video recorder and an audio recorder.

The lesson process integrated with Lesson Study was used from the fourth week until week fourteen. All the pre-service teachers were given early exposure to the implementation and benefits of Lesson Study. This exposure is important because the pre-service teachers did not have any experience and knowledge in Lesson Study (Burroughs \& Luebeck, 2010). In the second week, the discussion involved the formation of groups and the distribution of tasks. Next, in the third week, all the pre-service teachers sat in groups to choose a topic that matched the teaching method that was assigned to them. Then, in their groups, the pre-service teachers discussed goal setting and preparing a collaborative lesson plan.

In MLS, pre-service teachers act as teacher, students, and evaluators. Thus, the pre-service teachers' lesson in MLS consisted of three main perspectives: teacher's perspective, students' perspective, and evaluators' perspective. However, this study focused only on the evaluators' perspective in assessing the lesson. The next discussion will use the term teacher to refer to the pre-service teacher who acts as a teacher in the teaching and learning process. The term students is used to refer to pre-service teachers who act as students, and the term evaluators refers to the pre-service teachers who do the assessment throughout the teaching and learning process. The implementation steps of MLS are shown in Figure 1. 


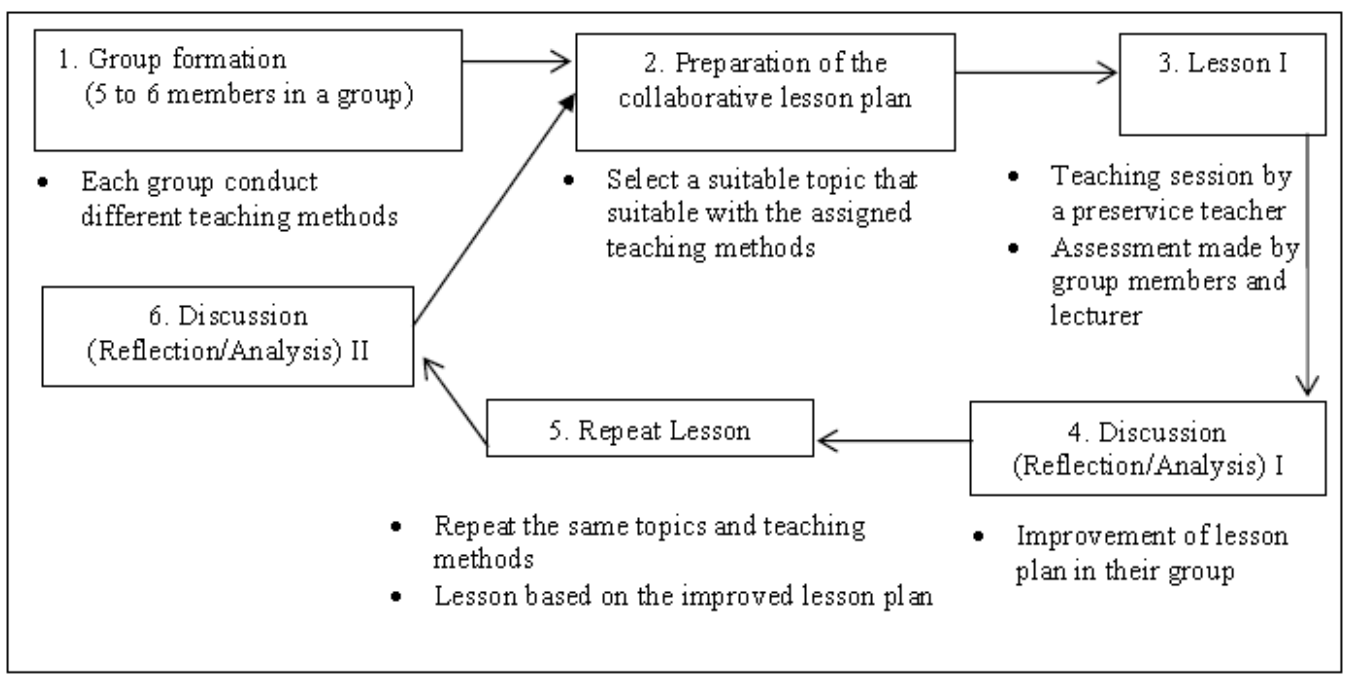

Figure 1. Model of microteaching and lesson study (MLS)

In the first step, five groups of five to six members were formed randomly. Each group was assigned to carry out one out of four different methods: experiment, demonstration's methods, lesson-based on problems, and ICT approach. Then, in the second step, each group chose a title that was suitable for the assigned teaching methods and prepared a collaborative lesson plan. Next, Lesson I was carried out based on the prepared lesson plan with a pre-service teacher appointed as the teacher and the rest of group members appointed as the evaluators. The evaluators then made an assessment during the lesson. During this stage, the lecturers also made an assessment and acted as experts who provide resources, feedback, and guidance (Fernandez, 2005). Outside evaluators were also invited to provide input related to the lesson.

The assessment made during the lesson was discussed once the lesson ended. In the Evaluation I stage, the pre-service teacher who acted as the teacher made a self-reflection while the rest presented their assessment to be discussed together. The weaknesses identified in the first lesson were used as guidelines in making improvements for the Repeat Lesson. Therefore, as Zanaton (2012) explained, in the Repeat Lesson, the same topic and teaching methods were used. A pre-service teacher (either the same or a different teacher from the Lesson I) was appointed to teach, and the rest of the group members were appointed as evaluators. Next, assessment and reflection about the Repeat Lesson were discussed during Discussion II. If necessary, this cycle was repeated to ensure the implemented MLS was able to enhance ability of pre-service teachers during the lesson.

This study involved the qualitative collection and analysis of the data. The data was collected throughout one semester in accordance with the implementation of the MLS in the Chemistry Teaching Method course. The data were collected from observation, interviews, and document. Video recording and audio recording (mp3) were also taken during Lesson I and II and Discussion I and II to facilitate the process of gathering and analyzing the data. The audio recording of the teaching, assessment, and interview then was transcribed. The sources of the observation were audio recording, pictures, and field notes. In addition, the document provided by pre-service teachers consisted of written reports and pictures. The written report consisted Lesson I and II, Assessment Report I and II, and Lesson I verbatim. Observation was conducted 10 times, and each group conducted two lesson based on the Lesson Study teaching cycle.

Multiple data sources were used to triangulate the data to obtain the validity and the reliability of the data (Patton, 2002). The researchers used Nvivo 8 to facilitate the data organizing. Analysis of the qualitative data was carried out with the Constant Comparative Analysis introduced by Glaser and Strauss in 1967 (Boeije, 2002). All the available data sources were compared systematically. By comparing the sources, researchers were able to categorize, coding and linking them. After the data comparison, reflection on the data was done. The comparative analysis and reflection was an ongoing process as each new data obtained were compared with the data that had already been analysed until reaching the saturation of data.

\section{Results and Discussion}

Analysis of the findings showed that pre-service teachers were able to explore and to build their skills in doing 
assessments during microteaching activities by using the Lesson Study approach. Through this approach, the assessment was made not only by the teacher who taught the lesson but also by all the group members. Findings from the research showed that the pre-service teachers' skills in making assessment during microteaching could be enhanced by integrating Lesson Study (MLS). The skills to do assessments were done in three ways based on the daily lesson plan (RPH) by referring to the lesson and by assessing the students' behaviour.

\subsection{Assessment Based on Daily Lesson Plan (RPH)}

Findings from the observation of the first step in the implementation of microteaching through the Lesson Study approach showed that teachers discuss while planning the lesson. The discussion is done collaboratively among the group members, which included the evaluators and teacher. The discussion was also used to find the right materials, which are the Curriculum Specification (HSP) and examples of lesson plans from the internet. In this regard, Lewis (2002a) stated that teacher needed to collaborate with the evaluators in preparing the lesson plan. All the group members then would achieve agreement and would come out with the learning objectives, skills to be achieves, and teaching and learning strategies to be used in the lesson.

During the lesson, the first strategy used by the evaluators was assessing based on the lesson plan. The evaluators compared and contrasted the prepared lesson plan with what was implemented by the teacher during the lesson. Thus, when making the assessment, the evaluators needed to refer to the lesson plan from RPH that had been prepared before the lesson (Mergler \& Tangen, 2010). This matter was acknowledged by Izul during an interview:

$$
\text { "evaluators was referring to the RPH when assessing." (IntK2 Izul) }
$$

There were three main points that needed to be referred from the lesson plan when doing the assessment: the implementation of the learning objectives, the integration of moral values, and the thinking skills. The evaluators noticed the improvement in teaching techniques from the first lesson to the second lesson, especially in the achievement of the learning objectives in RPH. This situation occurred as a result of the advised and proposed objectives made by the evaluators who were also the group members:

\section{"When assessing the students' understanding for the second time, I realize that there are many improvements done in the lesson. One of the improvement that obviously seen is teaching based on learning objectives" (Pen2Kump1 Ana)}

Other than that, the evaluators also constructed their assessment skills by observing the lesson to detect whether any new values, which had not been planned and specified in the RPH, arose. As stated by Asmi:

"...... while I assessing the moral values, I referred more to the values that have been planned in RPH as well as other values that occur during the lesson"(IntK2 Asmi)

The evaluators were also involved in preparing the lesson plan and identified the things that had been planned. Based on the assessment during the lesson, however, those things were not implemented; instead, the teacher implemented other unplanned values. This kind of change often occurs; therefore, the evaluators became more concerned about the lesson because the unplanned elements should also be assessed and reported.

The assessment process in MLS involved the entire lesson process. Thus, the pre-service teachers needed to assess not only the elements that had been planned but also the new elements that arose during the lesson. This step can build skills to assess in an explicit way because they are able to identify the elements that are not planned in RPH but appear during the lesson. It was proven by the following interview:

"there are also other elements that we have not mention in RPH that outside the teacher's planning” (IntK2 Izul)

It is proven when a comparison is made between the values in RPH with the values detected by the evaluators. The additional values then were reported in a written report. As a result of the comparison between critical and creative thinking skills (KBKK) in RPH with KBKK's elements, a written report made by the evaluators showed that there were additional elements of KBKK implemented in the lesson.

\subsection{Assessment Based on the Teaching Approach}

Pre-service teachers had been given early exposure to the two types of teaching approaches: the students-centred approach and the teacher-centred approach. Pre-service teachers were recommended to use the students-centred approach in their lesson. Assessments that were clear and specific were necessary in the lesson (Eksi, 2012). Findings from this research showed that teachers could do explicit assessment towards the planned teaching approach through comparative teaching methods. For example, pre-service teachers could compare and contrast the teaching approach used by the teacher with great clarity. Assessments that have been done towards the 
teaching approach gave an overview of the role of the teacher as a facilitator and the implementation of the students-centred approach.

Besides that, the evaluators clearly explained the techniques used by the teacher in the students-centred approach. In this approach, the teacher provides opportunities for the students to explore the lesson activity like the two following two quotations from the written report:

"While teacher make demonstration, there are several students ask for the teacher's permission to do the experiment by themself" (Pen2Kump2 Aya)

"The teacher gives opportunity to each student to try out the experiment" (Pen1Kump1 Ika)

In addition, the evaluators were also able to assess and to identify the differences between the teaching approach used by the teacher, either the students-centred approach or the teacher-centred approach. During an interview, an assessor said the following:

"There is no students' involvement in the demonstration during the first assessment which means the teacher done the demonstration alone. But, during the second assessment, the students try to do the demonstration with the teacher" (IntK2 Ati)

The assessment of the teacher's teaching strategy provided better understanding of the concept. Thus, by implementing the microteaching integrated with Lesson Study, the pre-service teachers were able to construct their assessing skills based on the identification of the teaching approach that they had planned together.

\subsection{Assessment of the Students' Behaviour}

The main objective of the assessment in MLS is to construct the pre-service skills in making assessments on the achievement of the students' learning objectives (Matthews et al., 2009). One of the methods that can be implemented to identify the achievements of learning objectives is observation of the students' behaviour during the teaching and learning session. One of the evaluators in an interview stated,

"we can observe the students' act and behaviour during the teaching and learning session. Either the students understand the lesson presented by the teacher or not." (IntK3 Wani)

In fact, by having the Repeat Lesson in MLS, evaluators can develop skills in assessing the lesson not only by observing the students' behaviour but also by being in the best position to observe activities done by the students (Watanabe, 2002). As stated in an interview,

“...during the first lesson, I make assessment based on my own understanding. Which means, I assess the students' behaviour, students' reaction towards the lesson, either its effective or not. But, during the second lesson, I got better understanding about assessment of students understanding. So, I approach the students, I observe the activity sheets, either they can answer it or not. If they are able to answer the questions, its indicate that the P\&P is effective" (IntK4 Ani)

The findings are supported by evidence from observations in which the evaluators approached the students during the second lesson to observe their behaviour and the lesson activities they carried out during the lesson. However, the evaluators' movement did not interfere with the P\&P so that the achievement of learning objectives could be done in the usual way.

\subsection{Perception of Pre-service Teachers on Assessment Process in MLS}

Besides able to improve skills in making assessment, the implementation of MLS is also able to help the pre-service teachers to improve their teaching skills. The weaknesses identified in the first lesson can help the pre-service teachers to do an evaluation and then to improve the next lesson together (Burden \& Byrd, 2003; Chassels \& Melville, 2009). It was acknowledged by Aya in an interview:

"through MLS, each teacher can improve their teaching” (IntK4 Aya).

For example, the evaluators noticed that the teacher did not give any opportunity to the students to explain their answers during the first lesson. Next, during the discussion on the reflection, they emphasized this problem. As a result, the problem was taken into consideration during the second lesson. The following was stated by a member of Group 5:

"If compare to the previous lesson, the teacher gives opportunity to the students to explain their answers for the given questions and checked either it correct or wrong, compared to the first lesson where the teacher explain the students' answers rather to ask them to make the explanations" (Pen2Kump5KPS) 
In addition, reflection on the teaching is also one of the important aspects in assessment (Lewis et al., 2006). Through MLS, the pre-service teachers expressed that they were able to get a meaningful experience in making accurate and explicit assessments, as described by one of the pre-service teachers who acted as the teacher:

"in the assessment aspect, we can observe deeply on how to make an assessment because if we do it by ourselves, we will not realize our own mistakes" (IntK2 Amy).

Thus, based on the findings of this research, MLS was proven to be able to increase the ability and the skills of pre-service teachers in making the assessment for a lesson. Each element in teaching became important because all the group members planned it together, and they felt excited to see its implementation even though there was only one teacher who will teach. In fact, via MLS, cooperation and collaboration between teachers can nurture in each step of its implementation.

\section{Conclusion and Implication of the Study}

Experience in MLS has helped the pre-service teachers to gain a better understanding of the teaching implementation started in the discussion step in preparing the lesson plan, the implementation of the lesson, and the assessment during the lesson. In fact, with the emphasis on the assessment aspect, the pre-service teachers learned the techniques that make the best assessment possible. The improvement in the second lesson plan and the Repeat Lesson were also able to help the pre-service teachers to improve their weaknesses and not to repeat the same mistakes from the first lesson.

Indeed, the implementation of MLS has given opportunity to the pre-service teachers to apply all the pedagogy theories they have learned. The findings obtained from this study can impact the new alternative in microteaching, especially in pre-service teachers' courses. Constructions of concrete and meaningful experiences are needed by pre-service teachers so that, when they enter the world of employment, they are able to become professional and dedicated teachers.

\section{References}

Amobi, F. A. (2005). Pre-service teachers' reflectivity on the sequence and consequences of teaching actions in a microteaching experience. Teacher Education Quarterly, 32, 115-130.

Bahagian Pembangunan Kurikulum Kementerian Pelajaran Malaysia. (2011). KSSR: Kurikulum Standard Sekolah Rendah. Malaysia: Kementerian Pelajaran Malaysa.

Bahagian Pendidikan Guru Kementerian Pelajaran Malaysia. (2011). Lesson Study: Pembelajaran Melalui Amalan Kolaboratif Guru. Malaysia: Kementerian Pelajaran Malaysia.

Boeije, H. (2002). A purposeful approach to the constant comparative method in the analysis of qualitative interviews. Quality and Quantity, 36(4), 391-409. http://dx.doi.org/10.1023/A:1020909529486

Burden, P. R., \& Byrd, D. M. (2003). Methods for effective teaching. Boston: Pearson Education.

Burroughs, E. A., \& Luebeck, J. L. (2010). Pre-service Teachers in Mathematics Lesson Study. The Montanna Mathematics Enthusiast, 7, 391-400.

Chassels, C., \& Melville, W. (2009). Collaborative, reflective, and iterative japanese lesson study in an initial teacher education program: benefits and challenges. Canadian Journal Education, 32(4), 734-763.

Creswell, J. W. (2012). Educational research. Boston: Pearson Education.

Eksi, G. (2012). Implementing more reflection in microteaching. Education and Science, 37(164), 267-282.

Fernandez, M. L. (2005). Learning through microteaching lesson study in teacher preparation. Action in Teacher Education, 26(4), 37-47. http://dx.doi.org/10.1080/01626620.2005.10463341

Fernandez, M. L. (2010). Investigating how and what prospective teachers learn through microteaching lesson study. Teaching and Teacher Education, 26, 351-362. http://dx.doi.org/10.1016/j.tate.2009.09.012

Gunn, C. L. (2010). Exploring MATESOL student 'resistance' to reflection. Language Teaching Research, 14(2), 208-223. http://dx.doi.org/10.1177/1362168810363940

Iksan, Z. H., Nor, S. N. A. M., Mahmud, S. N., \& Zakaria, E. (2012). Pengaplikasian prinsip "lesson study" dalam kaedah pengajaran sains. UKM Teaching and Learning Congress 2012. Kertas Kerja UKM Teaching and Learning Congress 2012. Anjuran Pusat Pembangunan Akademik, Universiti Kebangsaan Malaysia. Awana Genting Highland, Selangor.

Kilic, A. (2010). Learner-centered micro teaching in teacher education. International Journal of Instruction, 3(1), $77-100$. 
Lewis, C. C. (2002a). Lesson study: A handbook for teacher-led improvement of instruction. Philadelphia: Research for Better Schools.

Lewis, C. C. (2002b). What are the essential elements of lesson study. The California Science Project Connection, 2(6), 1-4.

Lewis, C. C., Perry, R., \& Hurd, J. (2004, February). A Deeper Look at Lesson Study. Educational Leadership Association for Supervision and Curriculum Development, 18-22.

Lewis, C. C., Perry, R., \& Murata, A. (2006). How should research contribute to instructional improvement? The case of lesson study. Educational researcher, 35(3), 3-14. http://dx.doi.org/10.3102/0013189X035003003

Matthews, M. E., Hlas, C. S., \& Finken, T. M. (2009). Using lesson study and four-column lesson planning with pre-service teachers. Mathematics Teacher, 102(7), 504-508.

Mergler, A. G., \& Tangen, D. J. (2010). Using microteaching to enhance teacher eficacy in pre-service teacher. Teaching Education, 21(2), 199-210. http://dx.doi.org/10.1080/10476210902998466

Muniarti, S., \& Radhi, A. M. (2010). Reformasi pendidikan di Malaysia merentas jalan baru. Selangor: Institut Kajian Dasar.

Patton, M. Q. (2002). Qualitative Research and Evaluation Methods. Thousand Oaks, CA: Sage Publications.

Perry, R. R., \& Lewis, C. C. (2009). What is successful adaptation of lesson study in the US? Journal of Educational Change, 10(1), 365-391. http://dx.doi.org/10.1007/s10833-008-9069-7

Saito, E., \& Sato, M. (2012). Lesson study as an instrument for school reform: A case of Japanese practices. Management in Education, 26(4), 181-186. http://dx.doi.org/10.1177/0892020612445101

Sang, M. S. (2012). Pedagogi untuk pengajaran dan pembelajaran. Selangor: Penerbitan Multimedia Sdn. Bhd.

Watanabe, T. (2002, March). Learning From Japanese Lesson Study. Educational Leadership Association for Supervision and Curriculum Development, 36-39.

\section{Copyrights}

Copyright for this article is retained by the author(s), with first publication rights granted to the journal.

This is an open-access article distributed under the terms and conditions of the Creative Commons Attribution license (http://creativecommons.org/licenses/by/3.0/). 